\title{
Synopsis and lectotypification of Solanum (Solanaceae) species endemic in the West Indies
}

\author{
by \\ Sandra Knapp \\ Department of Botany, The Natural History Museum, Cromwell Road, London SW7 5BD, United Kingdom. s.knapp@nhm.ac.uk
}

\begin{abstract}
Knapp, S. 2009. Synopsis and lectotypification of Solanum (Solanaceae) species endemic in the West Indies. Anales Jard. Bot. Madrid 66(1): 00-00.

The West Indies (Bahamas, Greater and Lesser Antilles) is an area of high species richness and more importantly, species-level endemism in many groups. Solanum (Solanaceae) is diverse in the region with 25 endemic species (S. bahamense is near-endemic, bringing number to 26). Nineteen of these taxa are single-island endemics, and some have not been re-collected since the early $20^{\text {th }}$ century. A synopsis of the species endemic to the West Indies is presented, with full synonymy and distribution; a single representative specimen is cited for each. All accepted names and synonyms are lectotypified where necessary; many of these taxa were described from collections in Berlin (B) that are no longer extant. Lectotypes newly designated here are illustrated.
\end{abstract}

Keywords: typification, historic collections, America, exploration, West Indies, Caribbbean, diversity.

\section{Introduction}

Solanum (Solanaceae) is one of the ten most speciesrich genera of angiosperms. With approximately 1,500 species distributed worldwide on all continents except Antarctica, Solanum encompasses a wide range of habitats, from deserts to tropical rain forests, and habits, from annual herbs to canopy trees. The genus, like the family Solanaceae, is most diverse in the Americas, and centres of species diversity in Solanum are found in the Andes of South America, Australia and East Africa. As part of the collaborative project "PBI Solanum: a world-wide treatment" (see Knapp \& al., 2004; http://www.nhm.ac.uk/solanaceaesource), descriptions of all species of Solanum together with details of types and nomenclature are being provided via

\section{Resumen}

Knapp, S. 2009. Resumen y lectotipificación de las especies endémicas de Solanum (Solanaceae) en las Antillas. Anales Jard. Bot. Madrid 66(1): 00-00 (en inglés).

Las Antillas (Bahamas, Grandes Antillas y Pequeñas Antillas) es un área con gran riqueza florística y, lo que es más importante, con alto nivel de endemicidad en muchos grupos. Solanum (Solanaceae) es un género muy diverso en la región, que tiene 25 especies endémicas (S. bahamense es casi endémica, con lo que el número se elevaría a 26). Diecinueve de estos táxones son endemismos de una sola isla, y algunos no se han vuelto a colectar desde principios del siglo Xx. Se presenta ahora una sinopsis de las especies endémicas de las Antillas, con todos los sinónimos y su distribución y con cita de un espécimen representativo de cada especie. Todos los nombres aceptados y sinónimos se han lectotipificado cuando ha sido necesario; muchos de estos táxones fueron descritos a partir de colecciones que se conservaban en Berlín (B) pero que han desaparecido. Los lectótipos designados aquí están ilustrados.

Palabras clave: tipificación, colecciones históricas, América, exploración, Antillas, Caribe, diversidad.

an on-line taxonomic resource, Solanaceae Source. One of the goals of the PBI Solanum project is to designate lectotypes for all Solanum names, helping to stabilise nomenclature and facilitate further taxonomic research.

The West Indies are usually defined as the islands of the Caribbean comprising the Greater Antilles (Cuba, Hispaniola, Jamaica, Puerto Rico), the Bahamas, and the Lesser Antilles (Windward and Leeward Islands), but excluding the islands of Trinidad and Tobago, which are of continental origin, and the Dutch Antilles. The geological complexity of the West Indies has meant that the region is a natural laboratory for studies of evolution and diversification (Ricklefs \& Bermingham, 2007). The region as a whole is of 
Table 1. Solanum species recorded in the West Indies (see Knapp, in press; Acevedo checklist web address; Solanaceae Source). Single island endemics are in bold (Cuba, 6; Hispaniola, 7; Jamaica, 3; Puerto Rico, 1; Virgin Islands, 1; St. Vincent, 1).

\begin{tabular}{|c|c|c|}
\hline Solanum species & West Indian distribution & World distribution \\
\hline S. acropterum Dunal & Jamaica & \\
\hline S. aculeatissimum Jacq. & Bahamas, Greater and Lesser Antilles (exotic) & \\
\hline S. aethiopicum L. & Cultivated in Lesser Antilles & Cultivated; originally from Africa \\
\hline S. americanum Mill. & Bahamas, Greater and Lesser Antilles & Worldwide \\
\hline S. bahamense L. & Bahamas, Greater and Lesser Antilles; all but Hispaniola & Florida \\
\hline S. betaceum Cav. & Cultivated & $\begin{array}{l}\text { Cultivated worldwide; originally from } \\
\text { South America }\end{array}$ \\
\hline S. bicolor Willd. & Lesser Antilles & Northern South America \\
\hline S. boldoense A.DC. & Cuba & \\
\hline S. campechiense L. & Greater Antilles & Mexico, Central America \\
\hline S. capsicioides All. & Greater Antilles & Central and South America \\
\hline S. carolinense L. & Greater Antilles & North America \\
\hline S. chamaeacanthum Griseb. & Cuba & \\
\hline S. conocarpum A. Rich. & Virgin Islands & \\
\hline S. crotonoides Lam. & Hispaniola & \\
\hline S. dendroicum O.E. Schulz \& Ekman & Hispaniola & \\
\hline S. diphyllum L. & Cultivated & $\begin{array}{l}\text { Mexico and Central America; widely } \\
\text { cultivated in tropics }\end{array}$ \\
\hline S. donianum Walp. & Bahamas, Greater Antilles & SE USA, Mexico \\
\hline S. elaeagnifolium Cav. & Bahamas, Greater and Lesser Antilles (exotic) & $\begin{array}{l}\text { Widespread invasive; originally from the } \\
\text { Americas }\end{array}$ \\
\hline S. ensifolium Dunal & Puerto Rico & \\
\hline S. erianthum D. Don & Bahamas, Greater and Lesser Antilles & $\begin{array}{l}\text { Widespread invasive; originally from the } \\
\text { Americas }\end{array}$ \\
\hline S. glaucescens Zucc. & Cuba (possibly cultivated) & Mexico \\
\hline S. gundlachii Urb. & Cuba & \\
\hline S. havanense Jacq. & Greater Antilles & \\
\hline S. hazenii Britton & Lesser Antilles & Mexico, Central and South America \\
\hline S. jamaicense Mill. & Greater and Lesser Antilles & Mexico, Central and South America \\
\hline S. lanceifolium Jacq. & Greater and Lesser Antilles & Mexico, Central and South America \\
\hline S. lycopersicum L. & Cultivated & Worldwide; originally from South America \\
\hline S. macrocarpon L. & Cultivated & Cultivated; originally from Africa \\
\hline S. maestrense Urb. \& Ekman & Cuba & \\
\hline S. mammosum L. & Bahamas, Greater and Lesser Antilles & $\begin{array}{l}\text { Widespread in cultivation; originally from } \\
\text { South America }\end{array}$ \\
\hline S. melongena L. & Cultivated & Cultivated worldwide; originally from Asia \\
\hline S. microphyllum (Lam.) Dunal & Bahamas, Greater Antilles & \\
\hline S. moense Britton \& Wilson & Cuba & \\
\hline S. myriacanthum Dunal & Greater Antilles (exotic) & Mexico, Central and South America \\
\hline S. nigrescens M. Martens \& Galeotti & Greater and Lesser Antilles & Mexico, Central and South America \\
\hline S. nudum Dunal & Bahamas, Greater and Lesser Antilles & Mexico, Central and South America \\
\hline S. orthacanthum O.E. Schulz & Hispaniola & \\
\hline S. pachyneurum O.E. Schulz & Cuba & \\
\hline S. pachyneuroides Amshoff & Cuba & \\
\hline S. polyacanthos Lam. & Hispaniola & \\
\hline S. polygamum Vahl & Greater Antilles & \\
\hline S. punctulatum Dunal & Jamaica & \\
\hline S. pyrifolium Lam. & Hispaniola & \\
\hline S. quitoense Lam. & Cultivated in Greater Antilles & South America \\
\hline S. rostratum Dunal & Virgin Islands (exotic) & $\begin{array}{l}\text { North America, Mexico and Central America; } \\
\text { widespread invasive }\end{array}$ \\
\hline S. rugosum Dunal & Greater and Lesser Antilles & Mexico, Central and South America \\
\hline S. schlechtendalianum Walp. & Greater Antilles & Mexico, Central and South America \\
\hline S. schulzianum Urb. & Hispaniola & \\
\hline S. seaforthianum Andrews & Bahamas. Greater and Lesser Antilles & $\begin{array}{l}\text { Northern South America, widespread } \\
\text { in cultivation }\end{array}$ \\
\hline
\end{tabular}


Table 1. (Continuation).

\begin{tabular}{|l|l|l|}
\hline Solanum species & West Indian distribution & World distribution \\
\hline S. selleanum Urb. \& Ekman & Hispaniola & \\
\hline S. sisymbrifolium Lam. & Greater and Lesser Antilles & $\begin{array}{c}\text { Widespread invasive; originally from } \\
\text { South America }\end{array}$ \\
\hline S. tampicense Dunal & Greater Antilles & Florida, Mexico and Central America \\
\hline S. tetramerum Dunal & Greater Antilles & \\
\hline S. torvum Sw. & Bahamas, Greater and Lesser Antilles & Worldwide in tropics \\
\hline S. triste Jacq. & Lesser Antilles & Northern South America \\
\hline S. troyanum Urb. & Jamaica & \\
\hline S. tuberosum L. & Cultivated & $\begin{array}{c}\text { Worldwide; originally from Andean South } \\
\text { America }\end{array}$ \\
\hline S. umbellatum Mill. & Greater Antilles & Mexico, Central and South America \\
\hline S. urens Dunal & St. Vincent & Widely cultivated; originally from Central \\
\hline S. wendlandii Hook.f. & Cultivated & America \\
\hline S. woodburyi Howard & Puerto Rico & \\
\hline S. wrightii Benth. & Cultivated & \\
\hline
\end{tabular}

composite character, with the Greater Antilles, Bahamas and Lesser Antilles each having different geological origins and histories (Iturralde-Vinent \& MacPhee, 1999). The Bahamas have their origins in the North American tectonic plate, and are older and more stable than the rest of the Archipelago (Mullins \& Lynts, 1977). The Greater Antilles are primarily of Central American crust origin (forming to the west of present day Central America and moving to the east on the Caribbean plate), while the Lesser Antilles are derived from a volcanic arc at the eastern edge of the Caribbean plate (Iturralde-Vinent \& MacPhee, 1999; Ricklefs \& Bermingham, 2007). The Caribbean region as a whole has its origin as islands no earlier than the middle Miocene (Iturralde-Vinent \& MacPhee, 1999), and the Caribbean tectonic plate has many blocks giving many of the islands a composite geological character (e.g., Hispaniola, Jamaica). IturraldeVinent and MacPhee (1999) posit land connections to northern South America (the GAARlandia hypothesis) during the Eocene-Oligocene transition, while others (Hedges, 1996; Glor \& al., 2005; Ricklefs \& Bermingham, 2007) suggest dispersal accounts better for taxon distribution patterns observed, particularly for vertebrates.

The West Indies is an area of considerable species richness in Solanum, but more interestingly, is home to many unusual and poorly known endemic species. Of the 62 species registered from the region (see Knapp, in press), 9 are introduced in cultivation, 28 are found elsewhere in the Americas and 25 are endemic. If we include Solanum bahamense L. as a near endemic (outside the West Indies it occurs only in Florida; it is included here, bringing the number of endemics to 26), then more than $1 / 3$ of the species in the region are found only there. Of these, 19 are single island endemics (see Table 1), making the West Indies critically important for the conservation of Solanum diversity. The vast majority of these taxa have not been included in any phylogenetic analysis, and Whalen (1984), in his conspectus of the spiny solanums considered most of them to be of uncertain affinities. A tentative division into morphological assemblages can be made, however, this should be regarded as preliminary at best, and many of these taxa are isolated both morphologically and probably phylogenetically (see Table 2). Bohs (pers. comm.) had considerable difficulties aligning the plastid DNA sequences of $S$. polygamum, the unusual dioecious species from the Virgin Islands (see Knapp \& al., 1998), so that it was not included in any analyses (Levin \& al., 2006; Weese \& Bohs, 2007). The West Indian endemic Solanum species are indeed morphologically unusual, and have combinations of characters not found elsewhere in the genus. It is apparent from morphology that radiations of Solanum have occurred within the West Indies, and that species present there will have their sister taxa in the region rather than outside. Phylogenetic analysis of these taxa will certainly contribute to our understanding of hypotheses of Caribbean biogeography, but as most of these taxa are rare and many have not been collected recently, exploration and re-collection is a priority. To this end, this synopsis is presented in order to highlight a promising area for future phylogenetic research. Taxa recorded as West Indian endemic Solanum but now regarded as synonyms of more widely distributed species are presented in Table 3.

Many of the Solanum species from the West Indies were described by O.E. Schulz, who worked in Berlin during the early part of the $20^{\text {th }}$ century. Schulz did not 
Table 2. Preliminary groupings for West Indian endemic Solanum.

\begin{tabular}{|c|c|}
\hline Species group & Putative component taxa \\
\hline Geminata clade (S. havanense species group of Knapp, 2008b) & S. acropterum, S. conocarpum, S. havanense, S. troyanum \\
\hline Dulcamaroid clade & S. boldoense, S. pyrifolium \\
\hline Brevantherum clade & S. punctulatum \\
\hline $\begin{array}{l}\text { Leptostemonum clade (S. torvum species group, Torva clade of } \\
\text { Levin \& al., 2006) }\end{array}$ & S. orthacanthum \\
\hline $\begin{array}{l}\text { Leptostemonum clade (S. bahamense species group; } \\
\text { Bahamense clade of Levin \& al., 2006) }\end{array}$ & S. bahamense, S. ensifolium, S. polyacanthos \\
\hline $\begin{array}{l}\text { Leptostemonum clade (putative } S \text {. tetramerum species group, } \\
\text { part of Robustum clade sensu Levin \& al., 2006) }\end{array}$ & S. microphyllum, S. tetramerum \\
\hline Leptostemonum clade (putative S. schulzianum species group) & $\begin{array}{l}\text { S. chamaeacanthum, S. gundlachii, S. pachyneuroides, } \\
\text { S. schulzianum, S. selleanum, S. urens }\end{array}$ \\
\hline $\begin{array}{l}\text { Leptostemonum clade (S. crotonoides species group, allied to } \\
\text { Torva clade fide Levin \& al., 2006) }\end{array}$ & $\begin{array}{l}\text { S. crotonoides, S. dendroicum, S. moense, S. pachyneurum, } \\
\text { S. woodburyi }\end{array}$ \\
\hline $\begin{array}{l}\text { Leptostemonum clade (incertae sedis, perhaps related to } \\
\text { Robustum clade of Levin \& al., 2006) }\end{array}$ & S. polygamum \\
\hline Incertae sedis & S. maestrense \\
\hline
\end{tabular}

Table 3. Species of Solanum recorded as endemic to the West Indies now regarded as synonyms of widespread taxa (for those taxa now recognised as members of the genus Lycianthes see Knapp, in press and http://botany.si.edu/Antilles/Westlndies/ catalog.htm).

\begin{tabular}{|l|l|}
\hline Solanum species & Accepted name \\
\hline S. antillarum O.E. Schulz & S. nudum Dunal \\
S. daturifolium O.E. Schulz & S. torvum Sw. \\
S. fragile Griseb. & S. schlechtendalianum Walp. \\
S. guanicense Urb. & S. campechiense L. \\
S. indecorum A. Rich. & S. americanum Mill. \\
S. marmeladense Urb. & S. campechiense L. \\
\& Ekman & Cordia alliodora (Ruiz \& Pav.) \\
S. mucronatum Urb. & Oken (Boraginaceae) \\
S. riedleii Dunal & Solanum schlechtendalianum \\
& Walp. \\
S. sagreanum A. Rich. & S. glaucescens Zucc. \\
\hline
\end{tabular}

cite herbaria for any of the collections he cited, so it is generally assumed that he examined sets of material of these plants at B. The specimens he examined in B are no longer extant, necessitating the lectotypification of all of his names, including those he coined in collaboration with Eric Ekman. Fortunately duplicates of many of these collections are widely distributed, and for the names associated with Ekman collections, the top set of this material, annotated by Ekman, is kept at S. I have been unable to trace duplicates of some of the collections used by Schulz, but none of these species are accepted names. In these cases I have not neotypified these names here in the hope that future searches will uncover duplicates of the collections upon which these epithets are based. I have not lectotypified Lamarck's names for Caribbean solanums, as these are represented in the Lamarck herbarium in $\mathrm{P}$ with single, clearly annotated sheets that link unambiguously with the protologues. Other names for which the authors unambiguously cited herbaria where they had seen material (e.g., Dunal often cited G-DC or G-Boiss. [now integrated into G] explicitly in his 1852 Prodromus treatment) have also not been lectotypified.

Reasoning for the choice of all lectotypes is given, along with the distribution of each species and a representative specimen from each island where it occurs. Where lectotypes have been chosen previously full reference is given, but reasoning for the choice not repeated here. Descriptions of all these species, discussions of their putative relationships, full specimen citations and distribution maps can be found on Solanaceae Source (http://www.solanaceaesource.org).

\section{Taxonomic synopsis of Solanum endemic in the West Indies}

Solanum acropterum Griseb., Fl. Brit. W.I.: 437. 1862

Type: Jamaica. sin. loc., J. Waters s.n. (lectotype, K [K000005250], designated by Knapp, 2008b: 409).

Distribution. Endemic to Jamaica, where it is found in woods on limestone soils in the cloud forests of the John Crow Mountains from 100-700 m.

Representative specimen. Jamaica. St. Thomas Parish, Stearn 499 (A, BM, K, MO, P, S).

Solanum bahamense L., Sp. Pl.: 118. 1753

Type: Bahamas. "Ins. Providentia", Anon. (lectotype LINN 248.42 [BH neg. 6822], designated by Knapp \& Jarvis, 1990: 328). 
Solanum racemosum Jacq., Enum. Syst. Pl.: 15. 1760

Type: Martinique, no specimens located (neotype, Jacquin, Select. Stirp. Hist. Amer. t. 36. 1763, designated by Howard, 1989: 293).

Solanum igneum L., Sp. Pl., ed. 2: 160: 1762

Type: No specimens located (lectotype, "Solanum spiniferum frutescens spinis igneis Americanum" in Plukenet, Phytographia, t. 225, f. 5. 1692, designated by Howard, 1989: 293).

Solanum fruticosum Mill., Gard. Dict. Ed. 8, no. 18. 1762

Type: Jamaica. sin. loc., W. Houstoun s.n. (lectotype, BM [BM000815974, BH neg. 5109], designated here).

Solanum varginstonicum Buc'hoz, Pl. Nouv. Découv. 48, tab. 46. 1784

Type: Pl. Nouv. Découv. 48, tab. 46. 1784. Type: Cultivated in Paris, no specimens located (lectotype, Buch'hoz, Pl. Nouv. Decouv. 48, t. 46. 1784, designated here).

Solanum igneum L. var. parvifolium Vahl, Eclog. Amer. 1:23. 1797

Type: U.S. Virgin Islands. St. Croix, D. West s.n. (holotype, C; isotype, G-DC [Morton neg. 8431]).

Solanum subarmatum Willd., Enum. Pl.: 240. 1809

Type: Cultivated at Berlin, of unstated origin, but apparently thought to be from Bahamas "Insula Providentia”, Anon. (holotype, B-W [B-W-4414]).

Solanum persicifolium Dunal, Nat. Hist. Solanum 1813

Type: No specimens cited in protologue (lectotype, Plumier, Pl. Amer. t. 244, fig. 2, 1760, designated here). as "persicaefolium".

Solanum anacanthum Dunal in DC., Prodr. 13(1): 183. 1852

Type: "Mexico", J. Pavón s.n. [unspecified locality in West Indies, M. Sessé E J. Mociño s.n.] (holotype, G [G-Boiss., F neg. 34108]; isotype, MA [MA-604598]).

Solanum igneum L. var. inerme Dunal in DC., Prodr. 13(1): 184.1852

Type: Cultivated, originally from St. Thomas, 1827 , H. Wydler 90 (lectotype, G-DC [IDC microfiche 80061.2077.III.8], designated here).

Solanum persicifolium Dunal var. angustifolium Dunal in DC., Prodr. 13(1): 185. 1852

Type: "Puerto Rico, St. Thomas", 1820, C. Bertero s.n. (holotype, G-DC [F neg. 33949, IDC microfiche 800-61.2077.I.2]; isotype, AV-Requien n.v.).

Solanum bahamense L. var. lanceolatum Griseb., Fl.

Brit. W.I.: 440. 1861
Type: Jamaica.("Solanum fruticosum bacciferum spinosum, flore caeruleo", lectotype, Sloane, Voy. Jamaica 1: t. 145, fig. 3, 1707, designated here; epitype, BM-SL [BM000589942], designated here).

Solanum bahamense L. var. subarmatum (Willd.) O.E. Schulz in Urb, Symb. Antill. 6: 222. 1909

Type: Based on Solanum subarmatum Willd.

Solanum racemosum Jacq. var. igneum (L.) O.E. Schulz in Urb., Symb. Antill. 6: 225. 1909

Type: Based on Solanum igneum L.

Solanum persicifolium Dunal var. parvifolium (Vahl)

O.E. Schulz in Urb., Symb. Antill. 6: 227. 1909

Type: Based on Solanum igneum L. var. parvifolium Vahl.

Solanum persicifolium Dunal var. belloi O.E. Schulz in Urb., Symb. Antill. 6: 227. 1909

Type: Puerto Rico. along seashore near Fajardo, 17 Feb 1900, A.A. Heller 4605 (lectotype, F [F-80757], designated here; isolectotypes, $\mathrm{B}$ [destroyed], $\mathrm{MO}$, NY [NY00144404], P [P00368434]).

Solanum bahamense L. var. luxurians D'Arcy, Ann. Missouri Bot. Gard. 61: 838. 1974

Type: USA. Florida: Monroe Co., Key Largo, 21 Oct 1967, W.G. D'Arcy 2234 (holotype, FLAS; isotype, MO [MO-1963193]).

Solanum bahamense L. var. rugelii D'Arcy, Ann. Missouri Bot. Gard. 61: 839. 1974

Type: USA. Florida: Monroe Co., Key West, F. Rugels.n. (holotype, MO).

Distribution. Widespread in the West Indies in coastal forests, forest margins and on beach margins, often on coral or calcareous soils, from 0-100 m. Absent from Hispaniola, but found on Ile la Tortue and Ile la Navasse off the NW coast of Haiti.

Representative specimen. Bahamas, Bimini, Cat Cay, Correll \& Correll 45600 (F, NY).

In describing Solanum fruticosum, Miller (1768) cited "Solanum fruticosum bacciferum, spinosum, flore caeruleo Sl. C. 108" and made reference to the collector William Houstoun. The specimen selected here as the lectotype for this name in BM is annotated with the same reference to Sloane, and bears a label in Houstoun's hand (Fig. 1a). It is also a good match for the description.

Solanum varginstonicum was named by Buc'hoz in honour of George Washington, with a spectacular misspelling of the name. No specimens have been traced for Buc'hoz's names, so the plate (Fig. 1b) is selected here as the lectotype.

In his description of Solanum persicifolium, Dunal 
(1813) cites two pre-Linnean sources; Plumier's (1703) catalogue ("Plumier cat. 4") bound with the Nova Plantarum Americanarum (Plumier, 1703) and the larger compilation of Plumier's American plants illustrated by Johannes Burman from tracings of Plumier's originals held in Paris ("Burm., Plant. Amer. p. 240, t. 244, fig. 2"; Plumier, 1755-1760, see Jarvis, 2007 for a discussion of Plumier's plates). On page 4 in Plumier's 1703 catalogue is the polynomial
"Solanum fruticosum, persicae foliis, aculeatum"; this same polynomial is associated with plate 244 in the illustrated edition (Plumier, 1757). In the Prodromus (Dunal, 1852), Dunal cites several specimens, stating that the Burman plate was "mala". The Burman plate, however, is the only verifiable element associated with the original description (although Dunal may have seen the originals in Paris) and is thus here selected as the lectotype (Fig. 1c).
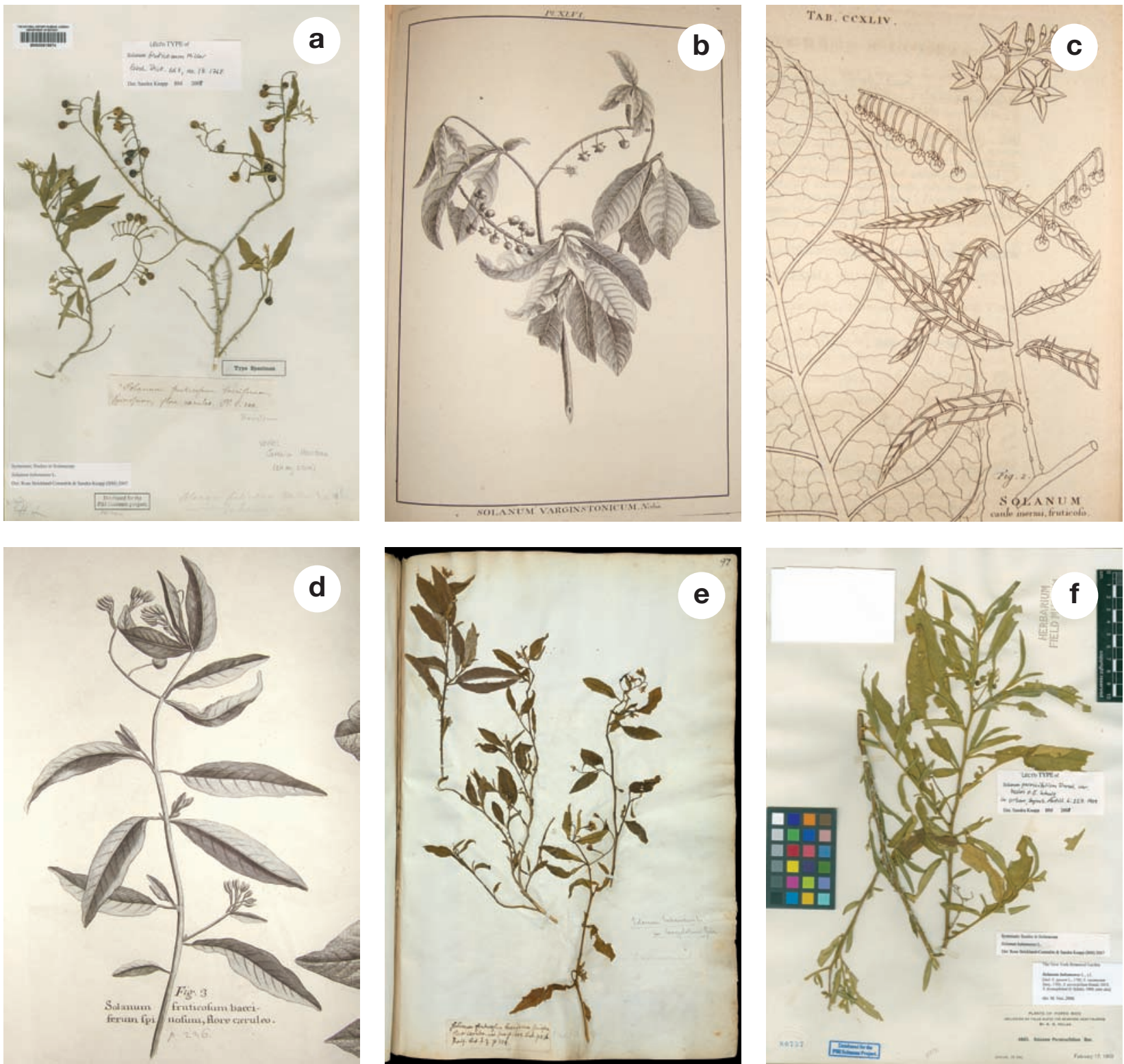

Fig. 1. Solanum bahamense L. a, Lectotype of S. fruticosum Mill., Houstoun S.n. (BM000815974); b, lectotype of S. varginstonicum Buc'hoz, Buc'hoz, Pl. Nouv. Découv. 48., t. 46, 1784. Reproduced with permission of the Natural History Museum Botany Library; $\mathbf{c}_{\mathbf{t}}$ lectotype of Solanum persicifolium Dunal, Plumier, Plant. Amer. t. 245, f. 2, 1763. Reproduced with permission of the Natural History Museum Botany Library; d, lectotype of S. bahamense var. lanceolatum Dunal, Sloane, Voy. Jamaica t. 145, fig. 3, 1707. Reproduced with permission of the Natural History Museum Botany Library; e, epitype of S. bahamense var. lanceolatum Dunal (BM000589942). Reproduced with permission of the Natural History Museum, London; f, lectotype of S. persicifolium var. belloi O.E. Schulz, Heller 4605 (F-80757). Reproduced with permission of the Field Museum of Natural History. 
Solanum igneum var. inerme was described by Dunal using two sheets in G-DC (Dunal, 1852), one without a collector from Cuba and the other a cultivated specimen from seeds send by Wydler from St. Thomas. He speculates that the un-armed nature of the plant is due to it being cultivated (Dunal, 1852), and places $S$. subarmatum tentatively in synonymy. The only unambiguously identifiable sheet cited is Wydler 90 from St. Thomas in the U.S. Virgin Islands; it is here selected as the lectotype (not illustrated).

In describing Solanum bahamense var. lanceolatum, Grisebach unambiguously cites a plate from Sloane as part of the diagnosis, and additionally assigned some of the specimens cited (without herbarium attribution) to this variety. I feel that he is specifically referring to the Sloane plate as the element on which he is basing his name, and merely identifying the other collections as belonging to one or the other variety, thus these specimens are probably not type material. Two specimens at GOET annotated "? lanceolatum" in Grisebach's hand are potential original material, but the Sloane plate is the only element unambiguously linked to the variety. I therefore have chosen the plate in Sloane's A voyage to the islands Madera ... Jamaica (1707-1725) labelled Solanum fruticosum bacciferum spinosum, flore caeruleo" as the lectotype of the variety (Fig. 1d). The epitype of this name with the same polynomial designation is found in the Sloane herbarium at BM (BM000589942, Fig. 1e).

Five collections were cited in the protologue of Solanum persicifolium var. belloi; Heller 4605, Sintenis 1260, Sintenis 1919 p.p., Eggers 35 and Benzoin s.n. Of these, Heller 4605 is the most widely distributed and has several sheets in very good condition and the sheet at F (Fig. 1f) is here selected as the lectotype.

Solanum boldoense Dunal \& A.DC., in Prodr. 13(1): 679. 1852

Type: Based on Solanum cardiophyllum Dunal, non Lindl.

Solanum cardiopbyllum Dunal in DC., Prodr. 13(1) 89. 1852. Cuba. "in Havana", B.M. Boldo s.n. (holotype, MPU).

Solanum scandens Sessé \& Moc., Fl. Mex., ed. 2, 53. 1894

Type: Cuba. Sessé E Mociño s.n. (lectotype, MA [MA-604676, F neg. 48318], designated by Knapp, 2008a: 20; isolectotype MA [MA-604675, F neg. 48343,5381 , upper frag. in photo, sheet now divided]).

Distribution. Endemic to Cuba, where it is found in forests and forest edges at low to middle elevations.
Representative specimen. Cuba, Pinar del Río, Ekman 17544 (S).

Solanum boldoense has occasionally been confused with the Mexican and Central American species $S$. dulcamaroides Dunal, to which it is probably closely related.

Solanum chamaecanthum Griseb., Cat. Pl. Cub.: 190. 1866

Type: Cuba. "in savanis prope Hanabana", 1865, C. Wright s.n. (lectotype, GOET [GOET0001970], designated here; isolectotype, GOET [GOET0001971]; possible isolectotypes (numbered 3634), GH [GH77546], K [K000196224], NY [NY00111375, NY00689170], S [S04-2892]).

Distribution. Endemic to Cuba, in low elevation swampy areas, common in the northwestern part of the island around Havana.

Representative specimen. Cuba, Camagüey, Ekman 8600 (S).

In describing $S$. chamaeacanthum, Grisebach (1866) did not cite a specific Wright collection number. Wright's duplicates are not all numbered, and some distributed without numbers are clearly duplicates of numbered collections. A sheet at GOET (GOET0001970) is labelled "savanas Habanana" and is an un-numbered Wright collection, making it the clear choice for a lectotype (Fig. 2a). Another sheet (GOET0001971) was annotated lectotype by R.A. Howard in 1984, but as it does not have the locality associated with the protologue has not been selected here as the lectotype.

Solanum conocarpum Rich. ex Dunal, in Poir., Encycl. Suppl. 3: 748. 1814

Type: US Virgin Islands. St. John: Coral Bay, L.C. Richard s.n. (holotype, P [P00325582]; isotype fragment, F [F-976721]).

Distribution. Endemic to the U.S. Virgin Islands, found in coastal thickets.

Representative specimen. U.S. Virgin Islands, St. John, Acevedo 5437 (K, MO).

Solanum crotonoides Lam., Tabl. Encycl. 2: 24. 1794

Type: "Martinique". sin. loc., J. Martin s.n. (holotype, P-LA [P00357672]).

Solanum reticulatum Dunal in Poir., Encycl. Suppl. 3:

764. 1814

Type: "Saint Domingue", [Hispaniola], P. Richard s.n. (holotype, P [P00325752, Morton neg. 8176]; fragment, F). 

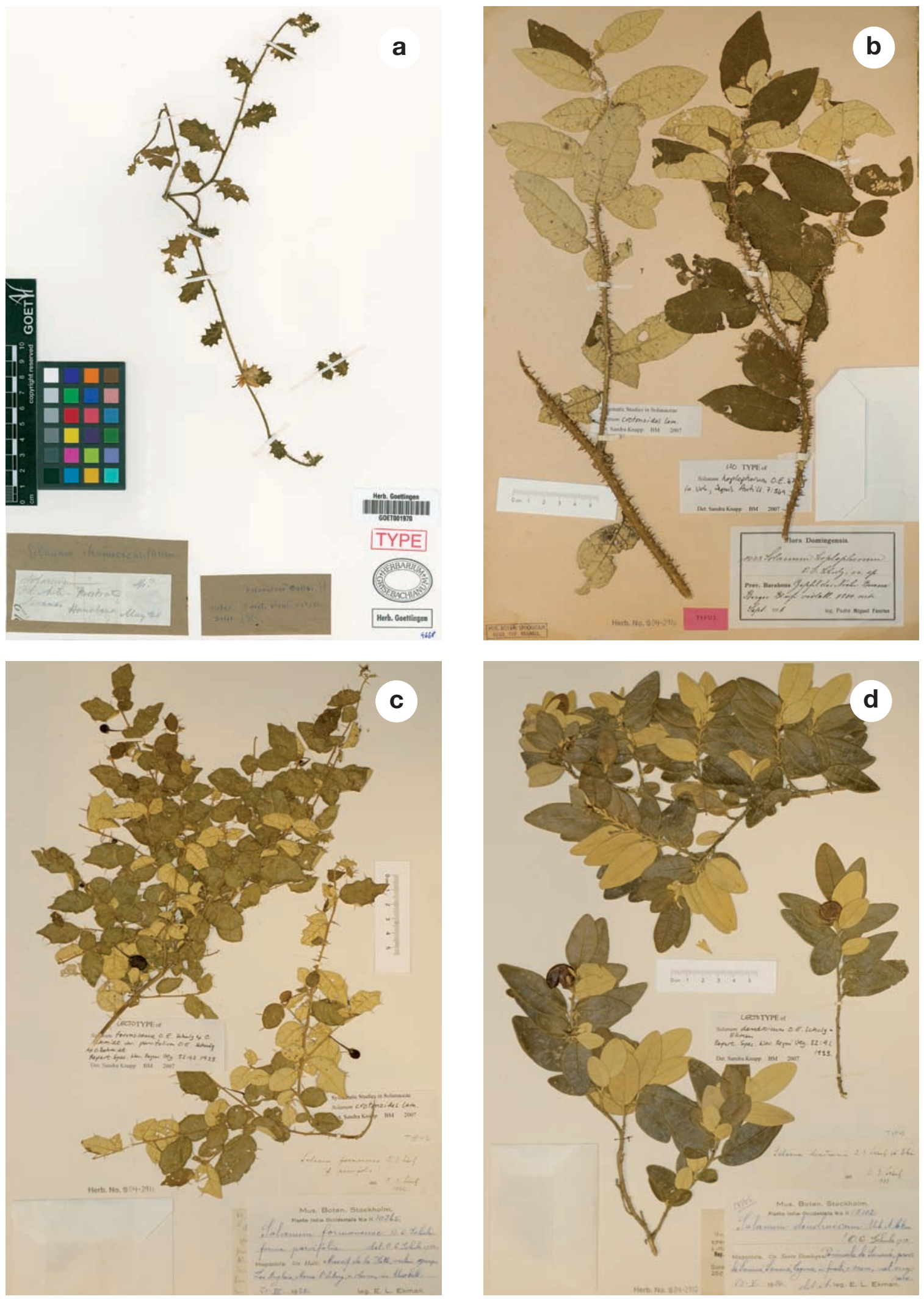

Fig. 2. a, lectotype of Solanum chamaeacanthum Griseb., Wright S.n. (GOET0001971); b, lectotype of S. hoplophorum O.E. Schulz, Fuertes 1023 (S04-2916) (=S. crotonoides Lam.). Reproduced with permission of the Swedish Museum of Natural History; c, lectotype of S. formonense O.E. Schulz and of S. formonense var. parvifolium O.E. Schulz, Ekman H.10265 (S04-2911) (= S. crotonoides Lam.). Reproduced with permission of the Swedish Museum of Natural History; d, lectotype of S. dendroicum O.E.Schulz \& Ekman, Ekman H.15102 (S04-2902). Reproduced with permission of the Swedish Museum of Natural History. 
Solanum hoplophorum O.E. Schulz in Urb., Symb. Antill. 7:369. 1912

Type: Dominican Republic. Barahona, Gippel des Noche Buena, 1800 m, Aug 1911, M. Fuertes 1023 (lectotype, S [S04-2916], designated here; isolectotypes, A [A00077555], BM [BM000629234], GH [GH00077554], GOET, K [K000196486], MO [MO-2572037]).

Solanum formonense O.E. Schulz ex O. Schmidt, Repert. Spec. Nov. Regni Veg. 32: 92. 1933

Type: Haiti. Massif de la Hotte, in parte occidentali, Les Anglais, Morne l'Etang, 1400 m, 21 Jul 1928, H. Ekman H.10365 (lectotype, S [S04-2911], designated here).

Solanum formonense O.E. Schulz ex O. Schmidt var. grandifolium O.E. Schulz ex O. Schmidt, Repert. Spec. Nov. Regni Veg. 32: 92.1933

Type: Haiti. Massif de la Hotte, western group, Torbec, M. Formon, 1700 m, 30 Dec 1926, E.L. Ekman H.7461 (lectotype, S, designated here).

Solanum formonense O.E. Schulz ex O. Schmidt var. parvifolium O.E. Schulz ex O. Schmidt, Repert. Spec. Nov. Regni Veg. 32: 92. 1933

Type: Haiti. Massif de la Hotte, western group, Les Anglais, Morne l'Etang, 1400 m, 21 Jul 1928, H. Ekman H.10365 (lectotype, S [S04-2911], designated here).

Distribution. Known only from the montane cloud forests of Hispaniola (Haiti and the Dominican Republic), from 1000-1800 m elevation.

Representative specimen. Dominican Republic. Prov. Peravia, Zanoni E Pimentel 40315 (JBSD, MO, NY).

Although Lamarck's protologue indicates that the plant collected by Joseph Martin came from Martinique, Solanum crotonoides has never been collected there. A similar situation exists for $S$. pyrifolium (Dulcamaroid clade), also collected by Martin from "Martinique". I suspect that Martin did in fact also visit Hispaniola (the locality for his type collection of Aquartia microphylla is "S. Domingo", see below) or that Martin used Martinique as a broad locality covering most of the Caribbean region, and that both these plants are true Hispaniolan endemics.

In describing $S$. formonense, Schulz and Schmidt did not designate which of the two varieties was typical. Sheets of both syntypes are held at S; Ekman H.10365 (S04-2911, Fig. 2b) is in excellent condition and is here used to lectotypify both the species and the variety. Ekman H.7461 is the lectotype for var. grandifolium, but is not figured here.

The lectotype of $S$. hoplophorum (Fig. 2c) is a very robust, prickly male plant (Fuertes 1023), showing that combination of characters that Dunal (1814) noted in describing $S$. reticulatum as the "hermaphrodite" of $S$. crotonoides (which is a dioecious species, see Knapp \& al., 1998). Both varieties of S. formonense are female plants.

Solanum dendroicum O.E. Schulz \& Ekman, Repert. Spec. Nov. Regni Veg. 32: 91. 1933

Type: Dominican Republic. Prov. Samaná, Peninsula de Samaná, near Samaná, Laguna, ca. 350 m, 21 May 1930, E.L. Ekman H.15102 (lectotype, S [S042902], designated here; isolectotypes, A [A0077457], K [K000196485], NY [NY00111365]).

Distribution. Endemic to the Samaná Peninsula of the Dominican Republic in northeastern Hispaniola, in matorrales and forests on limestone derived from ancient corals from sea level to $350 \mathrm{~m}$ elevation.

Representative specimen. Dominican Republic, Prov. Samaná, Peguero E Veloz 549 (JBSD, MO).

Of the four syntypes cited by Schulz (Ekman H.14847, Ekman H.15042, Ekman H.15102 and Abbott 2922), only one (Ekman H15102) is fertile. The sheet in S (Fig. 2d) has been chosen as the lectotype because Eric Ekman's top set of specimens is housed in Stockholm, all have been annotated by Ekman, and S04-2902 is in excellent condition.

Solanum ensifolium Dunal, in DC., Prodr. 13(1): 186. 1852

Type: "Mexico, J. Pavón" [Puerto Rico, M. Sessé E J. Mociño s.n.] (holotype, G [G-Boiss., F neg. 34117]; isotype, MA [MA-604619, F neg. 48338]).

Solanum drymophilum O.E. Schulz in Urb., Symb. Antill. 6: 227. 1909

Type: Puerto Rico, Cayey, Monte Llano, 25 Sep 1885, P. Sintenis 2374 (lectotype, BM [BM000886627], designated here; isolectotypes A [A00242857], CORD, F [F-79600, F-680330], GH [GH00242855], GOET, $\mathrm{K}$ [K000438174], M, MO [MO-2792753, MO5467986, MO-5468002], NY [NY00111367], P [P00367425, P00367426, P00367427, P00367428, P00367429], S, W).

Distribution. Endemic to Puerto Rico, in forests on low hills in the southern part of the island, to $800 \mathrm{~m}$.

Representative specimen. Puerto Rico, Mun. Salinas, Proctor 41918 (NY).

Many syntypes were cited in the original description of S. drymophilum; Sintenis 2025, Sintenis 2217, Sintenis 2121, Sintenis 2374, Sintenis 2480, Sintenis 5401. Of these, Sintenis 2374 is represented in many herbaria, and is composed a number of sheets in good condition with both flowers and fruit. I have selected 
the BM sheet as the lectotype (Fig. 3a) because it has all reproductive stages and is in good condition.

Solanum gundlachii Urb., Symb. Antill. 5: 487. 1908

Type: Cuba. sin. loc., C. Wright 3030 (lectotype, $\mathrm{GH}$ [GH00077553], designated here; isolectotypes, BM [BM000886657], MO [MO-2766697], GOET [2 sheets], K [K000196481], MA [MA-607704]).

Solanum hotteanum Urb. \& Ekman, Ark. Bot. 22(10): 51. 1929

Type: Haiti. Massif de la Hotte, western group, Tarbec, top of Morne Formon, ca. 2225 m, 1 Jan 1927, E.L. Ekman H.7489 (holotype, S [S04-2917]).

Solanum gundlachii Urb. var. monteverdense O. Schulz, in Urban, Symb. Antill. 6: 210. 1909

Type: Cuba. Monteverde, 800 m, H.F.A. von Eggers 5108 (holotype, B destroyed, no duplicates yet found).

Solanum lomense Britton \& P. Wilson, Bull. Torrey Bot. Club 53: 464. 1926

Type: Cuba. Prov. Oriente, Loma San Juan, near Loma del Gato, Hongolosongo, 22 Apr 1926, Bro. Clement 2520 (holotype, NY [NY00111364]) ("Bro. León" as collector in protologue). as "lomensis".

Solanum cristalense Amshoff, Rev. Soc. Cubana Bot. 13: 6.1956

Type: Cuba. Oriente: Pinares, el Prado, Nicaro, Mayari, J. Acuña E F. Zaguas 19778 (holotype, SV n.v.).

Solanum cristalense Amshoff var. macrospermum Hada?, Folio Geobot. Phytotax. Prague 5: 431.1971

Type: Cuba. Oriente: montibus Montecristo, E. Hada? 1421 (holotype, P).

Distribution. Only known from eastern Cuba and from Haiti, in pine woods from 700-2225 m elevation.

Representative specimen. Cuba, Santiago de Cuba, Herbario Flora de Cuba (HFC) 57223 (B).

The type collection of Solanum gundlachii (Wright 3030) is present in many herbaria, some of which have both flowers and fruit. The specimen at $\mathrm{GH}$ [GH00077553] has both flowers and mature fruits and is here selected as the lectotype. The sheet clearly represents two separate gatherings, as two labels bear different collection dates and appear to come from different localities (see Fig. 3b).

Solanum havanense Jacq., Enum. Syst. Pl. 15. 1760

Type: Jamaica. Tab. 35, Jacq., 1763 (neotype, tab. 35 in Jacquin, Select. Stirp. Amer. Hist. 1763, designated by Knapp, 2008b: 414).

Solanum coriaceum Hook., Bot. Mag. 54: tab. 2708. 1827
Type: Cultivated in England, the seeds said to be sent by R. Barclay from Mexico (lectotype, Hooker, Bot. Mag. 54: t. 2708. 1827, designated by Knapp, 2008b: 414).

Solanum hookerianum A. Spreng., Tent. Suppl. Syst. 9. 1828

Type: Based on Solanum coriaceum Hook.

Solanum myrtifolium Lodd., Bot. Cab. no. 1431. 1828

Type: Cultivated in London (lectotype, Loddiges, Bot. Cab. 25: t. 1431. 1828, designated by Knapp, 2008b: 414).

Solanum havanense Vell., Fl. Flumin. 82. 1829; Icones 2, tab. 94.1831

Type: Icon. Tab. 94, Brazil. Rio de Janeiro: Pharmocopolis (lectotype, Vellozo, Fl. Flumin. Icones 2: t. 94. 1831, designated by Knapp, 2008b: 414).

Diamonon coriaceum (Hook.) Raf., Fl. Tellur. 2: 76. 1836

Type: Based on Solanum coriaceum Hook.

Solanum byrsinum Voigt, Hort. Suburb. Calc. 511. 1845

Type: Based on Solanum coriaceum Hook.

Solanum vacciniifolium Dunal, in DC., Prodr. 13(1): 160. 1852

Type: Cuba. Havana, R. de la Sagra 294 (holotype, GDC [F neg. 33944, IDC microfiche 800-61.2075:I.2]).

Solanum havanense Jacq. var. vacciniifolium (Dunal) Griseb., Cat. Pl. Cub. 189. 1866

Type: Based on Solanum vacciniifolium Dunal.

Distribution. Endemic to the West Indies, found on Cuba, Jamaica and the Cayman Islands, in coastal woodlands on calcareous soils.

Representative specimen. Cuba, Cienfuegos, Webster E al. 51 (A).

Solanum maestrense Urb., Repert. Spec. Nov. Regni Veg. 21: 221. 1925

Type: Cuba. Oriente: Sierra Maestra, on the water divide between Rio Yara and Río Palmamocha, at the foot of Loma Joaquim, on the slope towards Rio Palmamocha, 19 Jul 1922, E. Ekman 14456 (lectotype, S [S04-2941], designated here; isolectotype, S [S042942]).

Distribution. Endemic to Cuba, known only from the type.

Representative specimen. Cuba, Oriente, Ekman $14456(\mathrm{~S})$.

It is clear from the protologue that Urban did not have at his disposal a specimen with a flower ("flores 

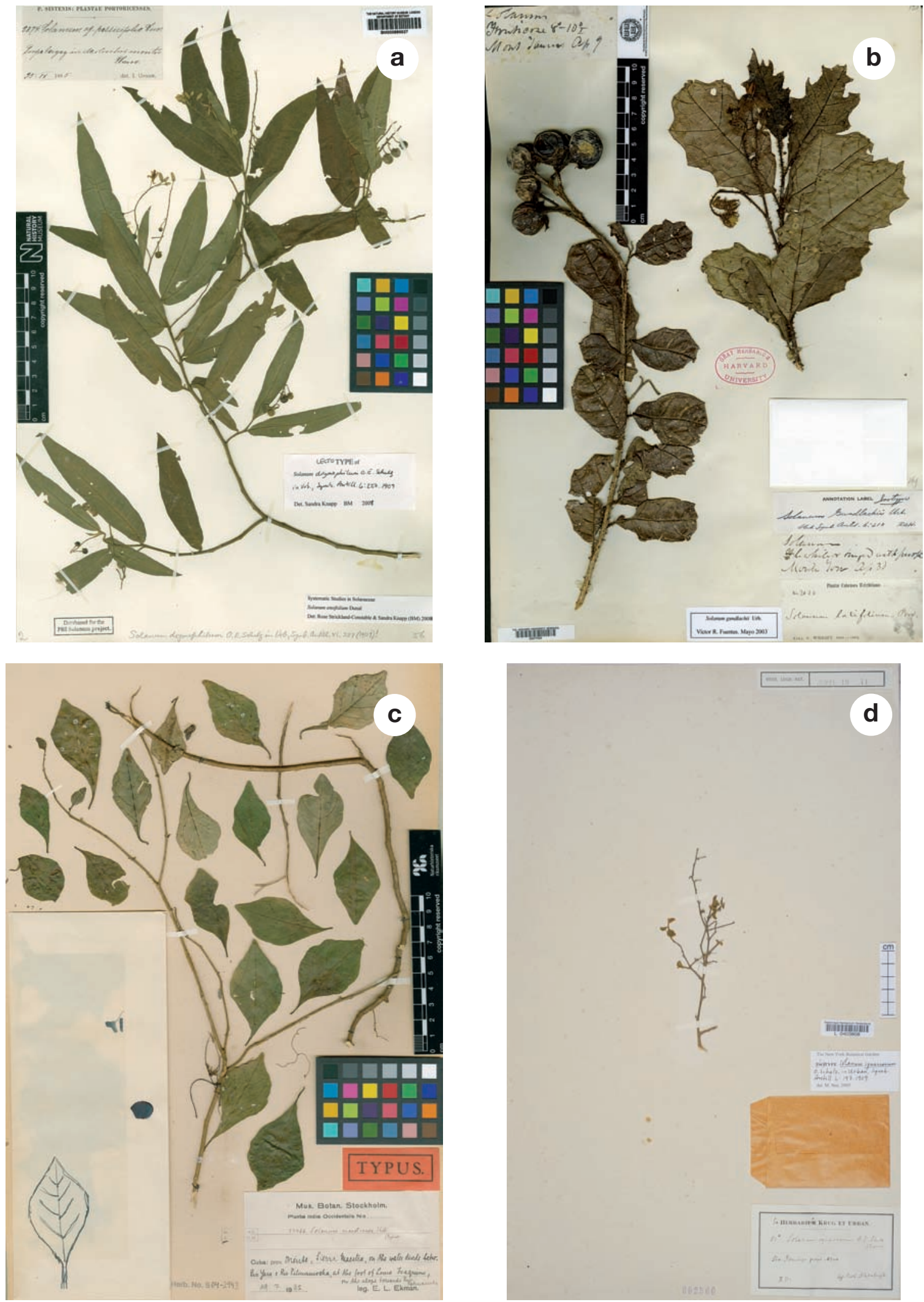

Fig. 3. a, lectotype of Solanum drymophilum O.E Schulz, Sintenis 2374 (BM000886627) (= S. ensifolium Dunal). Reproduced with permission of the Natural History Museum, London; b, lectoytpe of S. gundlachii O.E. Schulz, Wright 3030 (GH00077553). Reproduced with permission of Harvard University, Cambridge, Massachusetts, USA; c, lectotype of S. maestrense Urb., Ekman 14456 (S04-2941). Reproduced with permission of the Swedish Museum of Natural History; d, lectotype of S. squarrosum O.E. Schulz, Schomburgk 51 (L0403808). Reproduced with permission of the Natural History Museum of the Netherlands. 
non vidi", Urban, 1925), and that he was describing this species from material in B that is no longer extant. The two rather scrappy sheets at $\mathrm{S}$ are both annotated "type", but only one (S04-2941) has reproductive parts (one flower and two fruits in the packet). This sheet (Fig. 3c) is chosen here as the lectotype.

Solanum microphyllum (Lam.) Dunal, Hist. Solan. 187. 1813

Type: Based on Aquartia microphylla Lam.

Aquartia microphylla Lam., Tabl. Encycl. Meth. 1: 327, tab. 82, fig. 2. 1791

Type: "S. Domingo" [Dominican Republic], J. Martin s.n. (holotype, P-LA [P00357664]).

Solanum micropbyllum (Lam.) Dunal var. tomentosum Dunal in DC., Prodr. 13(1): 193. 1852

Type: "Santo Domingo", C. Bertero s.n. (holotype G-DC [IDC microfiche 800-61.2077:II.6]; isotype (probable), MO [MO-5468004]).

Solanum didymacanthum Millsp., Publ. Field

Columbian Mus., Bot. Ser. 2: 183. 1906

Type: Bahamas. Exuma: Hayne's road, 22-28 Feb 1905, N. Britton \& C. Millspaugh 3037 (holotype, F [F174174, F neg. 51388]; isotypes, $\mathrm{K}$ [K, NY [NY 00111366], US [US-849507, barcode US00027549]).

Solanum squarrosum O.E. Schulz in Urb., Symb. Antill. 6: 197.1909

Type: Dominican Republic. "prope Azua”, R. Schomburgk 51 (lectotype, L [L0403808], designated here).

Solanum gonaivense Leonard, J. Wash. Acad. Sci. 17: 71.1927

Type: Haiti. Dept. Artibonite, $8 \mathrm{mi} \mathrm{NE}$ of Gonaives, Ennery Road, 19 Feb 1926, E. Leonard 10007 (holotype, US [US-1301034, barcode US00588712]; isotype, $\mathrm{GH}$ [GH0077550]).

Distribution. In dry forests and xerophytic scrublands on Hispaniola and the Bahamas, usually on limestone soils at around sea level, but up to $200 \mathrm{~m}$ elevation.

Representative specimen. Bahamas, Little Exuma, Correll \& Wasshausen 51203 (MO, NY, US).

The type specimen of Solanum squarrosum was cited as Schomburgk 51 and was at B, but is no longer extant. A rather scrappy duplicate of Schomburgk 51 at Leiden (L0403808, Fig. 3d) is labelled "typus" in Schulz's hand and is here selected as the lectotype.

Solanum moense Britton \& Wilson, Mem. Torr. Bot. Club 16: 101. 1920

Type: Cuba. Oriente: Camp La Gloria, south of Sierra Moa, 24-30 Dec 1910, J.A. Schafer 8125 (holo- type, NY [NY00111363]; isotype, US [US-01047827, barcode US00027693]).

Distribution. Known only from a few collections in the Sierra de Moa in the eastern mountain ranges of Cuba.

Representative specimen. Cuba, Holguin, Herbario Flora de Cuba (HFC) 56400 (B).

Solanum orthacanthum O.E. Schulz in Urb., Symb. Antill. 7: 537. 1913

Type: Dominican Republic. Azua prov.,Valle de Yaque del Sur, 1300 m, Aug, M. Fuertes 1890 (lectotype, A [A00077559], designated here).

Solanum coelocalyx Alain, Phytologia 22: 170. 1971

Type: Dominican Republic. Constanza, El Motanzo, A.H. Liogier E E.J. Marcano 14716 (holotype, NY [NY00111376]; isotypes, BM [BM000886620], F [F1773526], GH [GH00231758]).

Distribution. Endemic to the eastern part of the island of Hispaniola in the Dominican Republic in moist areas in montane pine forest from 1200-1400 m elevation.

Representative specimen. Dominican Republic. Prov. La Vega, Zanoni E al. 23215 (JBSD).

The sheet of Fuertes 1890 at A (Fig. 4a) is the only duplicate of the type collection I have been able to trace, and thus I have chosen it as the lectotype of Solanum orthacanthum.

Solanum pachyneuroides Amshoff, Acta Bot. Neerland. 3: 418. 1954

Type: Cuba. Road to Delta Mine, Punta Gorda, Moa region, Jul 1949, Bro. Alain, Bro. Clemente E Bro. Chrysogone 912 (holotype, LS n.v.; isotype, US [US-2815217, barcode US00027721]).

Solanum pachyneurum O.E. Schulz var. glabrescens

O.E. Schulz in Urb., Symb. Antill. 6: 196. 1909

Type: Cuba. Sin. loc., 1860-1864, C. Wright 382 p.p. (holotype, B, destroyed; lectotype, GH [GH00112906, left hand stems, see below], designated here; isolectotype, K [K000196233]).

Distribution. Endemic to Cuba, known only from the eastern part of the island from pine woods at ca. 700 m elevation.

Representative specimen. Cuba, Guantanamo, Herbario Flora de Cuba (HFC) 42589 (B).

Wright 382, the type collection of Solanum pachyneurum var. glabrescens and a syntype of $S$. pachyneurum, is a mixed collection of $S$. pachyneurum (e.g., the sheet at BM [BM000886750] is $S$. pacbyneurum) and $S$. pachyneuroides (also see below). I have 

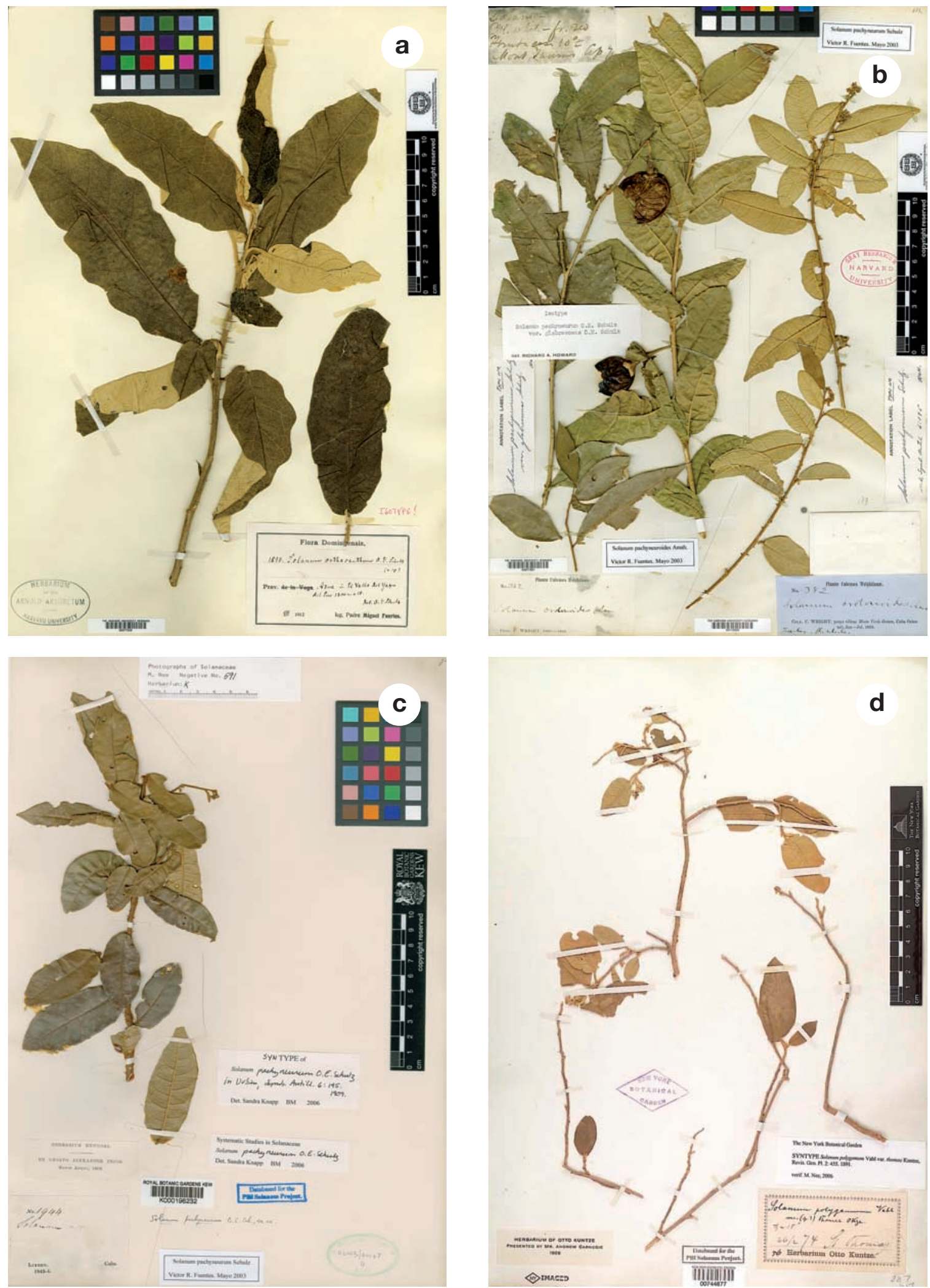

Fig. 4. a, lectotype of Solanum orthacanthum O.E. Schulz, Fuertes 1890 (A00077559). Reproduced with permission of Harvard University, Cambridge, Massachusetts, USA; b, lectotype of S. pachyneurum O.E. Schulz var. glabrescens O.E. Schulz, Wright 382 p.p. (left hand stems of GH00112906) (=S. pachyneuroides). Reproduced with permission of Harvard University, Cambridge, Massachusetts, USA; c, lectotype of S. pachyneurum O.E. Schulz, Linden 1944 (K000196232). Reproduced with permission of the Royal Botanic Gardens, Kew; d, lectotype of S. polygamum Vahl var. thomae O. Kuntze, Kuntze 36 (NY0074477) (= S. polygamum). Reproduced with permission of the New York Botanical Garden. 
chosen the left-hand two stems of GH00112906 (Fig. $4 \mathrm{~b})$ to lectotypify the varietal name; the right-hand stem and a small stem in the lower left corner are $S$. pachyneurum.

Solanum pachyneurum O.E. Schulz in Urb., Symb. Antill. 6: 195. 1909

Type: Cuba. Guantánamo: Santiago, prope Monte Libanon [Monte Libano], 1843, J. Linden 1944 (lectotype, K [K000196232], designated here; isolectotype, BM [BM000886751]).

Distribution. Endemic to eastern Cuba, in forests at about $700 \mathrm{~m}$ elevation.

Representative specimen. Cuba, Guantanamo, Herbario Flora de Cuba (HFC) 52625 (B).

Schulz (1909) cited three collections in his original description of Solanum pachyneurum - Wright 382, Eggers 5197 and Linden 1944. Wright 382, original material of both Solanum pachyneurum and S. pachyneurum var. glabrescens (a synonym of $S$. pachyneuroides, see above), consists of a series of mixed sheets of $S$. pachyneurum and $S$. pachyneuroides. It is not clear whether the two taxa occur sympatrically, or whether Wright assigned his numbers to plants collected after the fact, common practice at the time (and very likely). The latter case is suggested by the labeling of the sheet of Wright 382 at GH (see Fig. 4b). The sheet that Schulz examined in B has been destroyed, and other sheets of Wright 382 are mostly of $S$. pachyneurum, but some are a mixture of $S$. pachyneurum and $S$. pachyneuroides (see above). For this reason, it is more sensible to choose one of the many other syntypes of $S$. pachyneurum as the lectotype to avoid confusion. A sheet of Linden 1944 was not found at B and is presumably destroyed, but well preserved duplicates have been located at BM and K. Neither the K nor the BM sheet has any locality data, but the sheet at $\mathrm{K}$ (Fig. 4c) is better preserved, has reproductive parts and has therefore been selected as the lectotype.

Solanum polyacanthos Lam., Tabl. Encycl. 2: 23. 1794

Type: Cultivated in Paris from seeds from "St. Domingue" (Hispaniola), Anon. s.n. (holotype, P-LA [P00357671]).

Solanum parviflorum Cav., Icon. 3: 19, tab. 236. 1795

Type: Cultivated in Paris, from Santo Domingo, 1786, Anon. s.n. (lectotype, MA [MA-206020], designated by Knapp, 2007: 198).

Solanum polyacanthos Lam. var. oreophilum O.E. Schulz in Urb., Symb. Antill. 6: 200. 1909

Type: Haiti. Sin. loc., Nectoux s.n.; Furcy, Morne Tranchant, 1800 m, L. Picarda 245; sin. loc., Christ
1757; Kenshoff, 1400 m, W. Buch 915; Gonaives, Furcy, 1500 m, Oct 1903, W. Buch 949. as "polyacanthos". Solanum tortipes Urb. \& Ekman, Ark. Bot. 21(5): 59. 1927

Type: Haiti. Massif des Cahos, Petit Rivière de l'Artibonite, Pérodin, Jardins Nan-Plaine, 1400 m, 8 Mar 1925, E.L. Ekman H.3475 (holotype, S [S-04-2991]; isotype, US [US-1410723, barcode US00028728]).

Distribution. Known only from the island of Hispaniola (Haiti and the Dominican Republic), growing in a wide variety of forest types from dry thorn forest to cloud forest, from 300-1900 m.

Representative specimen. Dominican Republic, Prov. San Juan, Howard E Howard 8805 (BM).

I have located no duplicates of the five specimens were cited by Urban in describing Solanum polyacanthos var. oreophilum - Nectoux s.n., Picarda 245, Buch 915 and Buch 949, all from Haiti. A photograph of a duplicate of Buch 949 at IJ is held at MO and is clearly $S$. polyacanthos. I have not lectotypified this name here in the hopes of eventually finding and personally examining duplicates of the syntype material.

Solanum polygamum Vahl, Symb. Bot. 3: 39. 1794

Type: U.S. Virgin Islands. St. Croix, H. West s.n. (holotype, C).

Solanum inclusum Grisebach var. albiflorum Eggers, Bull. U.S. Natl. Mus. 13: 77.1879 [also included in Smithson. Misc. Colls. 23(3): 77. 1882]

Type: No specimen or specific locality cited.

Solanum polygamum Vahl var. thomae Kuntze, Revis. Gen. Pl. 2: 455. 1891

Type: U.S. Virgin Islands. Saint Thomas: sin. loc., O. Kuntze 36 (lectotype NY [NY0074477], designated here; isolectotype, K [K000196236]).

Distribution. Found in the central Caribbean on St. Thomas, St. Jan and St. John (US Virgin Islands), Tortola and Virgen Gorda (British Virgin Islands), Isla Vieques just to the southeast of Puerto Rico, in eastern Cuba and on southern Hispaniola from $0-350 \mathrm{~m}$ in limestone and sandy areas.

Representative specimen. British Virgin Islands, Virgin Gorda, Little E al. 23829 (BM).

Two syntypes were cited by Kuntze for Solanum polygamum var. thomae; Eggers 100 and Kuntze 36. Sheets of both of these were located at K; but the duplicate of Kuntze 36 at NY (Fig. 4d) is annotated by Kuntze and comes from his personal herbarium and is thus selected as the lectotype. Solanum inclusum var. albiflorum was described by Eggers in his Flora of St. Croix and the Virgin Islands (1879) without citing a 
specimen or a specific locality, but is clearly a synonym of $S$. polygamum. The description is of a female plant (S. polygamum is dioecious, see Knapp \& al., 1998), and I prefer to continue to search for fruiting material annotated by Eggers $S$. polygamum before neotypifying this name.

Solanum punctulatum Dunal in DC., Prodr. 13(1): 122. 1852

Type: Jamaica. sin. loc., 1819, J. Wiles [in herb. Lambert] s.n. (holotype, G [Morton neg. 8638]).

Distribution. Endemic to Jamaica, where it is found in forests and forest edges at high elevations.

Representative specimen. Jamaica, St. Thomas Parish, Stearn 99 (BM, K, S).

Solanum pyrifolium Lam., Tabl. Encycl. 2: 19. 1794

Type: "Martinica", sin. loc. [?Hispaniola], J. Martin s.n. (holotype, P-LA [P00357682]).

Solanum domingense Dunal in DC., Prodr. 13(1): 80. 1852

Type: Dominican Republic, sin. loc., Anon. s.n. (holotype, G [F neg. 33943]).

Distribution. Known only from the island of Hispaniola, primarily in the Dominican Republic, along forest edges on limestone and in cloud forests, from 120-1600 m elevation.

Representative specimen. Haiti, Holdridge 935 (BM, F).

Solanum schulzianum Urb., Symb. Ant. 5: 488. 1908

Type: Dominican Republic. Jimenes, 1190 m, 31 May 1887, H.F.A. von Eggers 2208 (lectotype, K [K000196492], designated here).

Solanum abbottii Leonard, J. Wash. Acad. Sci. 14: 415. 1924

Type: Dominican Republic. Prov. Pacificador, Quita Espuela, vic. San Francisco de Macoris, 900 m, 7 Apr 1922, W. Abbott 2073 (holotype, US [US1079509, barcode US0027429]; isotype, NY [NY00111371]).

Distribution. Known only from the eastern portion of the island of Hispaniola (collections only seen from the Dominican Republic) growing in forests from 300-1300 m elevation.

Representative specimen. Dominican Republic, Prov. Samana, Salazar E al. 1309 (JBSD).

Of the two syntypes cited in the original description (Eggers 1608, Eggers 2208), only Eggers 2208 was cited by Urban as being fertile; the Kew duplicate
(Fig. 5a) of this collection is therefore the most appropriate choice for a lectotype.

Solanum selleanum Urb. \& Ekman, Ark. Bot. 21(5): 60.1927

Type: Haiti. Massif de la Selle, Morne de la Selle, Croix des Bouquets, above Badeau, 1600 m, 28 Jan 1925, E.L. Ekman H.3127 (lectotype, S [S04-2981], designated here; isolectotypes, S [S-04-2982], US [US-1304052, barcode US00027793]).

Distribution. Only known from the island of Hispaniola, in valleys (Morne de la Selle, Haiti) at ca. $1600 \mathrm{~m}$. The type and one other sheet from the Dominican Republic (Zanoni \& al. 33773, not seen) are the only specimens of this species.

Representative specimen. Haiti, Ekman H.3127 (S).

Two sheets of Ekman H.1327 are in S, both annotated by Ekman. Of these, S04-2981 (Fig. 5b) is more complete, with both flowers and fruit, and is here selected as the lectotype.

Solanum tetramerum Dunal in DC., Prodr. 13(1): 681. 1852

Type: Cuba. Guantánamo, J. Linden 1986 (holotype, G-DC; isotypes, BM [BM000886483], K [K000196465], MO [MO-1058522]).

Aquartia aculeata Jacq., Enum. Pl. Carib. 1: 12. 1760

Type: Dominican Republic. "Domingo, ad sinum Bayaha" (no specimen located; neotype, Jacquin, Select. Stirp. Hist. Amer. t. 12. 1763, designated here). Solanum aquartia Dunal, Hist. Solan. 187. 1813

Type: Based on Aquartia aculeata Jacq. Nom. illeg. Solanum inclusum Grisebach, Fl. Brit. W. Ind. 441. 1861

Type: Cuba. sin loc., J. Linden 1986 (neotype, BM [BM000886483], designated here; isoneotypes, $\mathrm{K}$ [K000196465], G-DC, MO [MO-1058522]).

Solanum grisebachianum Kuntze, Revis. Gen. Pl. 2: 455. 1891

Type: Based on Solanum inclusum Grisebach.

Solanum cahosianum Urb. \& Ekman, Ark. Bot. 22(10): 49.1929

Type: Haiti. Massif des Cahos, near St.-Michel, road between Pol and Dessalines, $450 \mathrm{~m}$, 8 Jun 1927, E.L. Ekman H.8378 (holotype, S [S04-2889]).

Solanum miragonae Urb., Ark. Bot. 22(10): 50. 1929

Type: Haiti. Massif de la Hotte, group Morne Rochelois, Miragoane, limestone cliffs towards Anse-àVeau, 23 Nov 1926, E.L. Ekman H.7289 (lectotype, S [S04-2952]). 

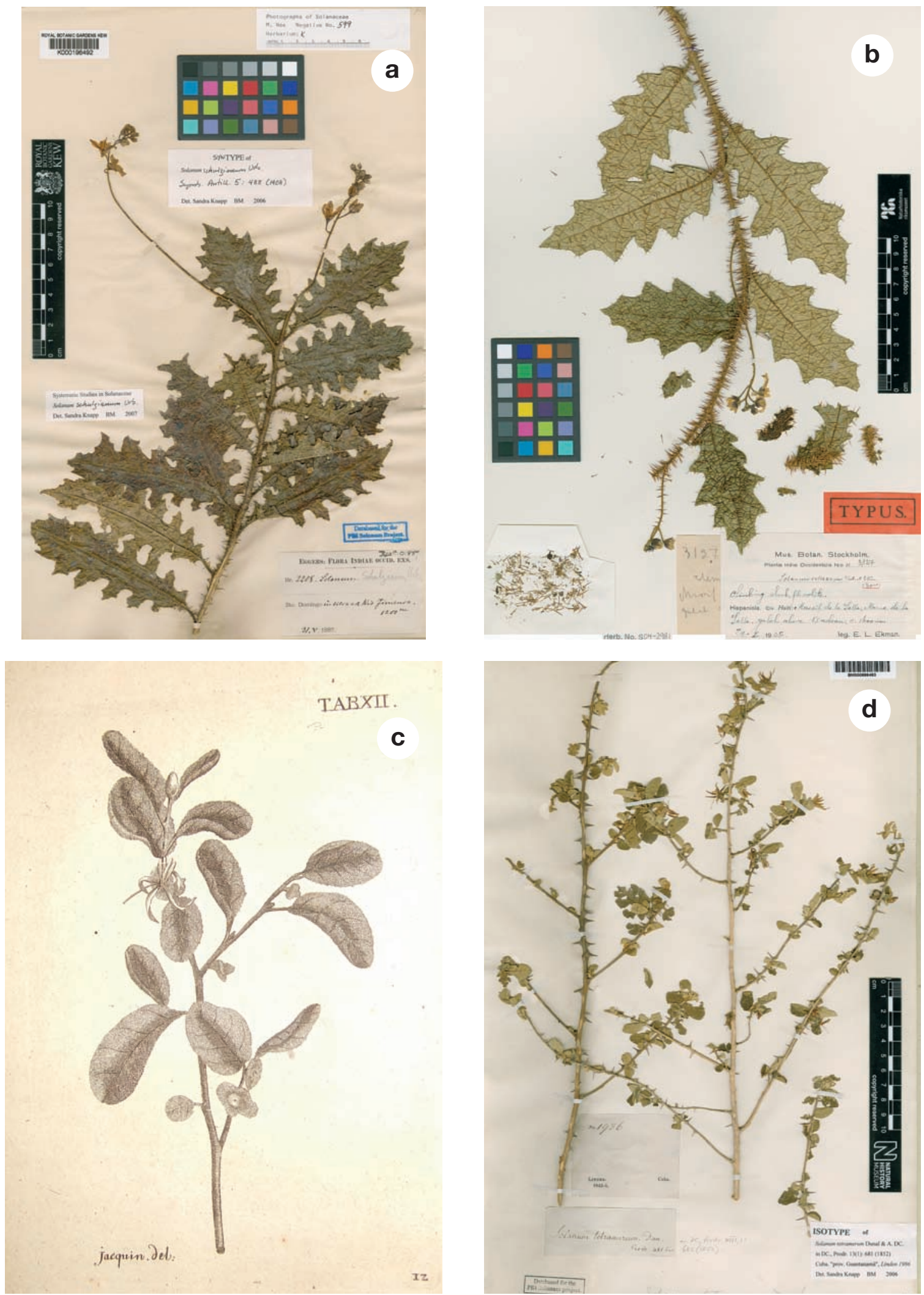

Fig. 5. a, lectotype of Solanum schulzianum Urb., Eggers 2208 (K000196492); b, lectotype of S. selleanum Urb. \& Ekman, Ekman H.3127 (S04-2981). Reproduced with permission of the Swedish Museum of Natural History; c, lectotype of Aquartia aculeata Jacq. Jacquin, Select. Stirp. Amer. t. 12, 1763) (=S. tetramerum Dunal). Reproduced with permission of the Natural History Museum Botany Library; d, neotype of S. inclusum Griseb., Linden 1986 (BM000886483) (= S. tetramerum Dunal). Reproduced with permission of the Natural History Museum, London. 
Solanum aculeatum (Jacq.) O.E. Schulz in Urban, Symb. Ant. 6: 196. 1909

Type: Based on Aquartia aculeata Jacq.

Solanum aculeatum (Jacq.) O.E. Schulz var. fuertesii

O.E. Schulz in Urban, Symb. Ant. 7: 370. 1912

Type: Dominican Republic. Barahona prov., "am Duvergé fluss”, 50 m, Aug 1910, M. Fuertes 384 (lectotype, NY [NY00111372], designated here; isolectotypes, E [E00202467], US [US-658349, barcode US00027440]).

Solanum aculeatum (Jacq.) O.E. Schulz var. luxurians

O.E. Schulz ex O. Schmidt, Repert. Spec. Nov.

Regni Veg. 32: 91.1933

Type: Haiti. Massif des Matheux, Thomazeau, Morne-a-Cabrits, 400 m, 17 May 1928, E.L. Ekman H.9979 (lectotype, S [S04-2827], designated here; isotype, K [K000196473]).

Solanum aquartia Dunal var. fuertesii (O.E. Schulz) Alain, Phytologia 70: 150. 1991

Type: Based on Solanum aculeatum (Jacq.) O.E. Schulz var. fuertesii O.E. Schulz.

Solanum aquartia Dunal var. luxurians (O.E. Schulz) Alain, Phytologia 70: 150. 1991

Type: Solanum aculeatum (Jacq.) O.E.Schulz var. luxurians O.E. Schulz ex O. Shmidt.

Distribution. In forests and scrub on limestone dry hills on Cuba, Hispaniola and Jamaica, from sea level to $400 \mathrm{~m}$ elevation.

Representative specimen. Jamaica, Saint Catherine Parish, Proctor 32768 (BM).

There has long been confusion over the correct name for this species. Dunal's (1813) re-naming of Jacquin's Aquartia aculeata as Solanum aquartia was illegitimate, but the name was used for many years. By the time Schulz (1909) made the correct combination Solanum aculeatum, the name Solanum aculeatum St.Lag. had been validly (but illegitimately) published as a replacement for Solanum aculeiger Dunal (now recognised as a synonym of the Brazilian species $S$. thomasiifolium Sendtn., see Solanaceae Source, http://www.solanaceaesource.org). The oldest available name for this species is $S$. tetramerum.

No specimen of Aquartia aculeata attributable to Jacquin has been found, despite intensive searches in many herbaria (principally BM, LINN and W) where such a sheet, if it had ever existed, might have been preserved. No original material was cited in the protologue (Jacquin, 1760), so any type selected must be a neotype. The illustration of $A$. aculeata in Jacquin's first illustrated edition of the Selectarum Stirpium Americanarum Historia (Jaqcuin, 1763), a copper engraving taken from original drawings done by Jacquin in the field (see Wiltshear, 1913) is very accurate, and I have chosen it here as the neotype of the species (Fig. 5c).

Solanum inclusum was described without specific collection or locality but said to be widespread across the Caribbean and in northern South America (Grisebach, 1861). Various subsequent authors have suggested that Grisebach's $S$. inclusum included both $S$. tetramerum and $S$. polygamum. No specimens have been identified at GOET that can be directly linked to Grisebach's naming of S. inclusum. In his Cuban catalogue Grisebach (1866) cited specimens as $S$. inclusum that are now identified as S. tetramerum ( $\mathrm{Lin}$ den 1986, 2000). Specimens indicated as type material of S. inclusum in some herbaria (i.e., Wright 1350 in GH) are in fact $S$. torvum. Since Grisebach (1861) did not indicate any specimens or specific localities for his name, these sheets cannot be considered type material. I neotypify Grisebach's Solanum inclusum here with the BM duplicate (Fig. 5d) of Linden 1986 in order to stabilise usage (synonymy) of this ambiguous name.

No duplicates of Ekman H.7289, the type of Solanum miragonae, are extant at B, and the only sheet of this collection encountered is at $\mathrm{S}$, so this is the clear choice as the lectotype (Fig. 6a). It may be that the $\mathrm{S}$ sheet is the holotype, as $S$. miragonae was described in a Swedish journal along with other taxa whose types are in S, but as there is no evidence of this, I prefer to lectotypify the name here.

Solanum aculeatum var. fuertesii was described using several collections: Fuertes 384, 386 and 396. Of these, Fuertes 384 has been located in several herbaria, the NY duplicate is here selected as the lectotype (Fig. 6b). In describing variety luxurians, with larger, more repand leaves, several syntypes were cited: Ekman H.2318, Ekman H.6732, Ekman H.8548, Ekman H.9979 and Ekman H.8773. The duplicate of Ekman H.9979 in S (Fig. 6c) has an annotation label in Schulz's hand with the varietal name luxurians, and is the logical choice for a lectotype.

Solanum troyanum Urb., Symb. Antill. 5: 487. 1908

Type: Type: Jamaica. Trelawney Parish: Mount Diablo, 29 Aug 1905, W. Harris 9000 (lectotype, BM [BM000849163], designated by Knapp, 2008b: 419; isolectotypes, K [K000005227], NY [NY00111387]).

Distribution. Endemic to Jamaica, in the Blue Mountains in forests and forest edges at middle to high elevations.

Representative specimen. Jamaica, Trelawny Parish, Proctor 24845 (A, BM, NY, US). 

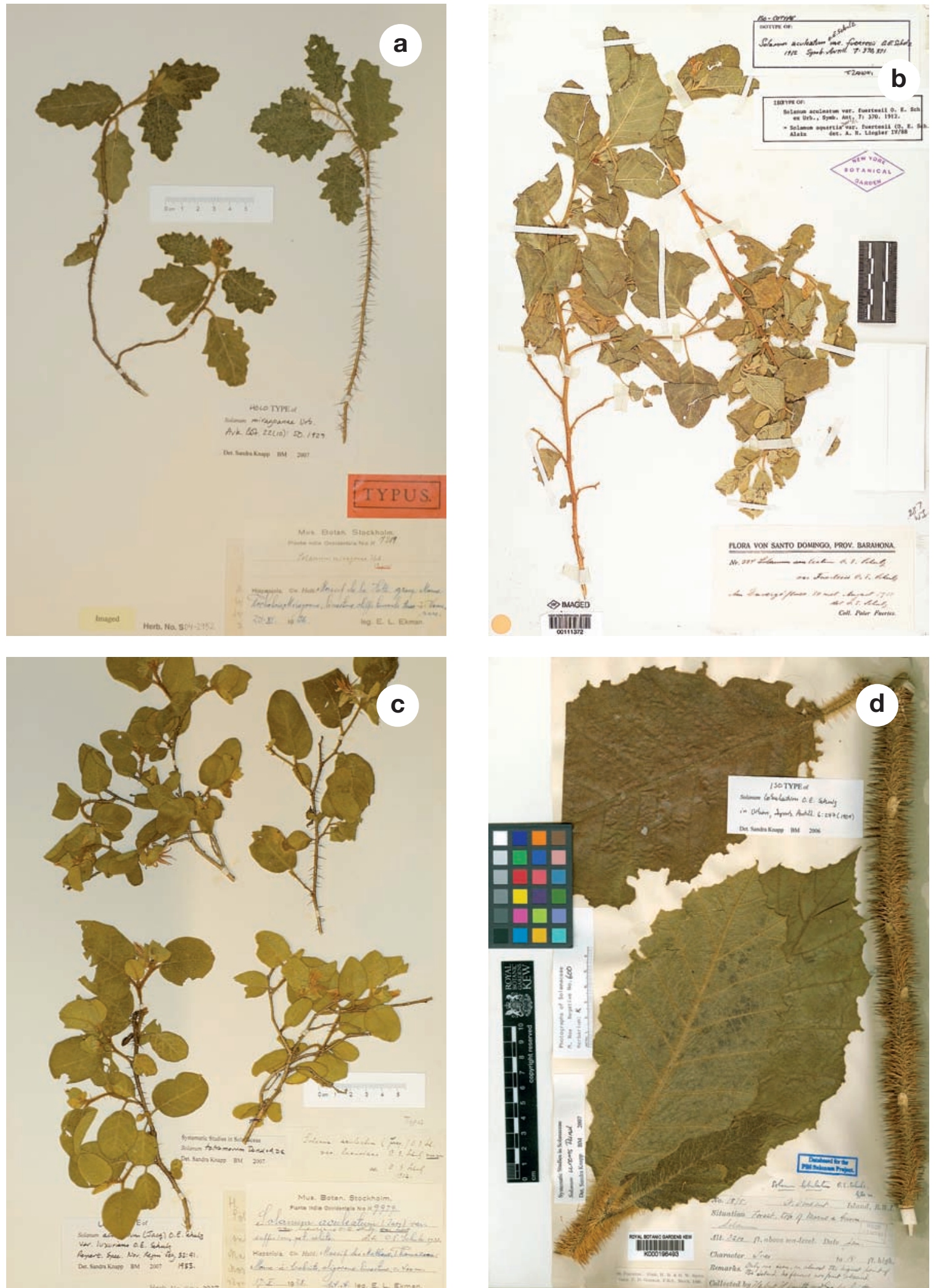

Fig. 6. a, lectotype of Solanum miragoanae Urb., Ekman 7289 (S04-2952) (= S. tetramerum). Reproduced with permission of the Swedish Museum of Natural History; b, lectotype of S. tetramerum Dunal var. fuertesii O.E. Schulz, Fuertes 284 (NY00111372) (= S. tetramerum Dunal). Reproduced with permission of the New York Botanical Garden; c, lectotype of S. tetramerum var. luxurians O.E. Schulz, Ekman H.9979 (S04-2827) (= S. tetramerum Dunal). Reproduced with permission of the Swedish Museum of Natural History; d, lectotype of S. Iobulatum O.E. Schulz, Smith \& Smith 1575 (K000196493) (= S. urens Dunal). Reproduced with permission of the Royal Botanic Gardens, Kew. 
Solanum urens Dunal in DC., Prodr. 13(1): 311.1852

Type: St. Vincent and the Grenadines. St. Vincent: Bonhomme, A. Anderson s.n. (holotype, G-DC [Morton neg. 8649]).

Solanum lobulatum O.E. Schulz in Urb., Symb. Ant. 6: 247. 1909

Type: St. Vincent and the Grenadines. St. Vincent: Morne Garou, 960 m., H.H. Smith \& G.W. Smith 1575 (lectotype, K [K000196493], designated here).

Distribution. Only known from montane areas on the island of St. Vincent, at approximately $1000 \mathrm{~m} \mathrm{el}$ evation.

Representative specimen. St. Vincent and the Grenadines, St. Vincent, Howard E al. 17711 (BM, NY).

Schulz did not cite a herbarium when describing Solanum lobulatum, and no sheet of Smith E Smith 1575 is extant at $\mathrm{B}$. The $\mathrm{K}$ duplicate of this collection is here designated the lectotype (Fig. 6d) as no other duplicates have been found, but are likely to exist. Solanum lobulatum was described from sterile material, Schulz (1909) stated that the specimen he examined was annotated "we have only seen one root"; from the morphology of the specimen at $\mathrm{K}$ it is clear that this is a juvenile individual with a single stem.

Solanum woodburyi Howard, J. Arnold Arb. 47: 138. 1966

Type: Puerto Rico: S side Luquillo Mountains, El Toro trail, $2 \mathrm{~km}$ from route 191, 13 Oct 1964, R.A. Howard \& G. Taylor 15692 (holotype, A [A00077564]; isotypes, BM [BM000815969], LE, MO [MO638820], NY [NY00111390], US [US-3079749, barcode US00027856]).

Distribution. Endemic to the Luquillo Mountains in eastern Puerto Rico; known only from the East Peak region in the Bosque Nacional del Caribe from 150 to 200 m elevation in deep, wooded ravines.

Representative specimen. Puerto Rico, Mun. Luquillo, D’Arcy 1716 (MO).

\section{Acknowledgements}

I thank the curators of the herbaria cited in the text for use of material in their care and for the kind provision of and permission to use images; Michael Nee (NY) for discussions on locating Solanum type specimens, Pedro Acevedo-Rodriguez (US) for encouragement to work in the West Indies, and Charlie Jarvis (BM) for discussions on all aspects of typification; this work has been funded by the National Science Foundation Planetary Biodiversity Inventory Program (award DEB-0316614 'PBI Solanum - a worldwide treatment' - http:nhm.ac.uk/solanaceaesource) and my visit to MA from the SYNTHESYS Project http://www. synthesys.info/ which is financed by European Community Research Infrastructure Action under the FP6 "Structuring the European Research Area” Programme. Reviewer's comments much improved the manuscript.

\section{References}

Dunal, M.-F. 1813. Histoire naturelle, médicale et économique des Solanum et des genres qui ont été confundus avec eux. Montpellier.

Dunal, M.-F. 1814. Morelle, Solanum. In: J.L.M. Poiret (ed.), Encyclopédie méthodique, Botanique, Suppl. 3: 738-780. Paris: Chèz H. Agasse.

Dunal, M.-F. 1852. Solanaceae. In: A.P. de Candolle (ed.), Prodromus systematis naturalis regni vegetabilis 13(1): 1-690.

Eggers, H.F.A. von. 1879. The flora of St. Croix and the Virgin Islands. Bulletin of the United States National Museum 13: 1-133 (also included in Smithsonian Miscellaneous Collections 23(3): 1-133. 1882).

Glor, R.E., Losos, J.B. \& Larson, A. 2005. Out of Cuba: overwater dispersal and speciation among lizards in the Anolis carolinensis subgroup. Molecular Ecology 14: 2419-2432.

Grisebach, A. 1861. Flora of the British West Indian islands, parts 4-5. Lovell, Reeve \& Co., London.

Grisebach, A. 1866. Catalogus Plantarum Cubensium. W. Engelmann, Leipzig.

Hedges, S.B. 1996. Historical biogeography of West Indian vertebrates. Annual Review of Ecology and Systematics 27: 163-196.

Howard, R.A. 1989. Solanaceae in Flora of the Lesser Antilles 6: 264-297.

Iturralde-Vinent, M.A. \& MacPhee, R.D.E. 1999. Paleogeography of the Caribbean region: implications for Cenozoic biogeography. Bulletin of the American Museum of Natural History 238: 1-95.

Jacquin, N.L. 1763. Selectarum stirpium Americanarum bistoria. Vienna: Krauss.

Jacquin, N.L. 1780. Selectarum stirpium historia iconibus pictus. Vienna: Pritzel.

Jarvis, C. 2007. Order out of chaos: Linnaean plant names and their types. Linnean Society of London and the Natural History Museum, London.

Knapp, S. 2007. Lectotypification of Cavanilles' names in Solanum (Solanaceae). Anales del Jardín Botánico de Madrid 64: 195-203.

Knapp, S. 2008a. Typification of Solanum (Solanaceae) species described by Sessé and Mociño. Anales del Jardín Botánico de Madrid 65: 7-23.

Knapp, S. 2008b. A revision of the Solanum havanense species group (section Geminata (G. Don) Walp. pro parte) and new taxonomic additions to the Geminata clade (Solanum: Solanaceae). Annals of the Missouri Botanical Garden 95(3): 405458.

Knapp, S. in press. Solanaceae. In: P. Acevedo-Rodriguez \& M.T. Strong (eds.), Catalogue of Seed Plants of the West Indies. Smithsonian Institution, Washington DC. (http://botany.si. edu/Antilles/WestIndies/catalog.htm).

Knapp, S., Bohs, L. , Nee, M. \& Spooner, D.M. 2004. Solanaceae: a model for linking genomics and biodiversity. Comparative and Functional Genomics 5: 285-291.

Knapp, S., Persson, V. \& Blackmore, S. 1998. Pollen morphology and functional dioecy in Solanum (Solanaceae). Plant Systematics and Evolution 210: 113-139.

Levin, R.A., Meyers, N.R. \& Bohs, L. 2006. Phylogenetic relationships among the "spiny solanums" (Solanum subgenus Leptostemonum, Solanaceae). American Journal of Botany 93: 157-169. 
Mullins, H.T. \& Lynts, G.W. 1977. Origin of the northwest Bahama platform: review and reinterpretation. Geological Society of America Bulletin 88: 1147-1161.

Plumier, C. 1703. Nova plantarum Americanarum genera. Paris.

Plumier, C. 1757. Plantarum Americanarum fasciculus primus (...decimus) continens plantas quas olim Carolus Plumierus .. depinxit has edidit... Johannes Burman. Amsterdam.

Ricklefs, R. \& Bermingham, E. 2007. The West Indies as a laboratory of biogeography and evolution. Philosophical Transactions of the Royal Society, B 363:2393-2413.

Schulz, O.E. 1909. Solanacearum genera nonnulla, in I. Urban (ed.) Symbolae Antillanae 6: 140-279.

Sloane, H. 1707-1725. A voyage to the islands Madera .... Jamaica. 2 vols. London.
Urban, I. 1925. Sertum antillanum XXIII. Repertorium Specierum Novarum Regni Vegetabilis 21: 213-230.

Weese, T. \& Bohs, L. 2007. A three-gene phylogeny of the genus Solanum (Solanaceae). Systematic Botany 33: 445-463.

Whalen, M.D. 1984. Conspectus of Solanum subgenus Leptostemonum. Gentes Herbarum 12: 179-282.

Wiltshear, F.G. 1913. LII. Jacquin's 'Selectarum Stirpium Historia Iconibus Pictus'. Journal of Botany 1913: 140.

Associate Editor: S. Castroviejo Received: 25-XI-2008 Accepted: 17-II-2009 